The old in experience and young in mind have ever boen outstanding leaders, but the old in mind and years are unable to grasp the new problems or to relate new knowledge to spiritual values. They fear youth and from a mistaken sense of duty they continue to bear burdens beyond their years, and are barring advance.

"It is vital to reach the younger generation, the parents of the future in service and civil life, and gain their intellectual interest and emotional drive behind the idea that man may control and direct to the service of man the forces that he has set in motion. Experience is needed, but so are drive, a new outlook, and faith in man's destiny."

To this must be added the all-important quality of leadership-a character which is not based on experience but is the outcome chiefly of initiative, imagination, determination and faith, and therefore a character no more the prerogative of the older generations than of any others. When a youth shows ability to lead, let him lead. Those of mature age might well offer him the benefit of their longer experience and guide and advise him ; but often they ignore him, and sometimes also they usurp his leadership once he has shown the way.

The President of the British Association, intervening after Mr. Riley's remarks at the Conference, expressed his sympathy with the younger scientific investigators; but there are some in authority who do not attempt to exercise such sympathy, at any rate in a practical form. Furthermore, many young men of science ask for more than sympathy ; they justly demand more practical recognition as men of science in their own right and not merely as scientific assistants. By keeping them as subordinates until middle age they often lose their capacity and desire for responsibility and initiative; they are sapped of their self-confidence. The President also pointed out that so far as the Division for the Social and Industrial Relations of Science is concerned, youth has played an im- portant part in its development. This is as it should be, especially since the Division itself is a youth. So now let the older institutions and societies and other research organizations follow this example and admit youth to their council chambers. A certain amount of balanced and controlled rejuvenation would not come amiss.

In his message to the International Youth Rally, the Prime Minister, referring to present-day needs, told youth that their place is still in the forefront of battle. H.M. the King, on the other hand, looking to the future, emphasized the gravity of the tasks which the years of reconstruction will lay upon the shoulders of youth. The two go together; they are inseparable. So also should youthful and older men of science march together, their individual status being acknowledged on grounds of scientific achievement and of intellectual, not chronological, age. Youth has a case; at present much of youth is being penalized. Until that unfair imputation is removed (and now is the time to do it), unity of purpose and team work can never be fully developed.

As pointed out in Nature of October 11, p. 427 :

"It seems well worth while investigating how to bring about the necessary unity of feeling, and to arouse sufficient enthusiasm among people agreed intellectually upon the work to be done in order to enable them to.pull together as a team. Co-opting more of the younger men in the counsels of science will undoubtedly help much towards this badly needed unity. At present some of the more progressive men of science feel keenly the neglect of their services, especially when older authorities are complaining of having too much to do, too many committees to attend, etc. Once this feeling almost of frustration is eliminated, and younger men are given their rightful place in the advancement of science, a closer unity of feeling. will be established."

\title{
THE NUTRITION SOCIETY
}

\begin{abstract}
A NEW scientific society devoted to the study of nutrition, the Nutrition Society, has just come into existence (see NATURE of October 11, p. 433), and an account of its first meeting appears on p. 519 of this issue. Nutritional thought in Great Britain has so far centred around the Biochemical and Physiological Societies, and in recent years the Nutrition Panel of the Society of
\end{abstract}

Chemical Industry has done much to foster interest in food problems. Admirable as these facilities were, they could not keep pace with the increasing scope of nutritional science which now also embraces agriculture, clinical study, practical dietetics and sociological problems. The new Society, while in no sense competing with existing ones, will provide a common meeting-ground 
where all aspects of nutrition can be discussed by workers previously separated by the barriers of specialization.

The formation of this body is thus in a measure the expression of the recent rapid development of a science and of the strong position it has always held in Great Britain. In addition, although the atmosphere of war is seldom propitious for the development of learning, it has contributed to the creation of this new academic fellowship. A new spirit is abroad among men of science, who realize that scientific detachment is no longer possible under conditions of total war or after it, and that they have the right and the duty to ensure that the results of their labours are properly used in the cause of humanity. At this time, when the problem of feeding the people is of vital importance to the country, the desire to do something immediately useful is probably foremost in the minds of the members of the new Society. In fact, this spirit had already manifested itself during the year preceding the formation of the Society, in informal exchanges between various workers of views on matters of nutritional importance.

The determination to put to practical use the accumulated nutritional knowledge is evident from the wish of the Society to limit the discussion at its meetings to certain specific topics, rather than to open it to the free presentation of isolated academic papers. Very appropriately the first meeting dealt with the evaluation of nutritional status. Every student of nutrition observes with a sense of shame and frustration the prevalence of malnutrition in this world of plenty. It is staggering to read a pronouncement by the President of the United States of America, that in that country, the richest in the world, undernourish. ment is widespread and serious. For this unhappy situation the man of science is not wholly blameless, and his attitude of aloofness shares censure with the shortcomings of the politician. In this connexion it is good to hear Mr. Eden express the hope which reflects the spirit of the British Association, that science and statecraft will henceforth march together. Thus might men of science and statesmen inspire and stimulate each other.

A similar desire for the scientific guidance of human affairs has also animated the virile and fruitful National Nutritional Conference for Defense which has recently met in the United States. It has acknowledged frankly that the State machinery in the United States has not given sufficient attention to the nutritive qualities of human foods, that "interest in general has been more in protecting pocket books than health" and that in fact livestock has been given the best parts of many foods.
It cannot be said that matters are any better in Great Britain. While agriculture in this country displays very rightly a keen interest in the forage and fodder value of its products, it is little, if at all, concerned with their value in human nutrition. The value of agricultural produce as human food is rarely considered much before the stage of actual consumption; previous to that, in the stage of production and distribution, it is just a marketable commodity. Much has been heard about the marriage of health and agriculture, but it is only with scientific planning that this union will bear fruits of high nutritive value.

With the formation of the new Society a hope for the future is raised in that workers in nutrition from all spheres will get together and pool their knowledge, plan their work on a practical basis, and combine to see that the greatest possible benefit to mankind is derived from the results. It takes little imagination to foresee that the proper nutrition of the people will form the foundation of future health programmes, and here the Nutrition Society will doubtless supply much creative planning. Many data are already to hand and it will be for the Society to see that such information is better utilized in the future.

In the meantime nutrition workers in Great Britain, going about their immediate war-time tasks, will derive inspiration and support from its meetings. When the time comes some and probably many of them will take an active part in the relief of the widespread misery and starvation which Nazi rule has brought on the subjugated peoples. Ample opportunities for humanitarian service will present themselves to the Nutrition Society which, we are informed, has had the happy thought of making early contact with its American counterpart -the American Institute of Nutrition-and with leading students of nutrition in that country. It is to be hoped that they will join hands in this work of reconstruction.

It is auspicious and fitting that Sir John Orr should have been called to be the first chairman of the Society. One of the few to realize the seriousness of the nutritional problems of Great Britain, he has now for many years, with pertinacity and courage, called for a constructive policy for the scientific feeding of the people. His voice has for too long been unheeded, but things have changed and his guidance in matters of nutritional planning is now frankly acknowledged on both sides of the Atlantic. Further, the Society may be proud that it has been ushered into being by Sir Frederick Gowland Hopkins, the doyen of nutritional science, whose great work will always be, in the future, as in the past, an inspiration to all who labour in this field. 